\title{
The Sociocultural Aspects of Merchant Class in the Light of Russian Painting Art
}

\author{
Kamile Sinem Kucuk \\ PhD Cand., İstanbul University, Turkey
}

\begin{abstract}
The merchant class, which contributed to the improvement of Russia, evolved due to politicial reforms. Especially in 1861 the emancipation reform of the Russian serfs caused social and culturel changes in the life of merchants. In 19th and early 20th century, the works of Russian genre painters P.A. Fedetov, A.P. Ryabushkin, V.G. Perov, F. Juravlev and B.M. Kustodiyev not only reflected the social situation and stereotypes of merchants, but also revealed cultural history of the mentioned class. In this paper it is aimed to disclose the evolution of merchant class in 19th and the early 20th century, observing and analysing the art of Russian painting in sociocultural perspective.
\end{abstract}

Keywords: Merchant, Russian Painting Art, Daily Life, The emancipation reform of Russian serfs, 19th century.

\section{Introduction}

Throughout world history, first civilizations were formed and developed under favour of trade and merchants. Since no human group could invent by itself more than a small part of its cultural and technical heritage. External stimulation of merchants, in turn, has been the most important single source of change and development in art, science and technology (Curtin, 2002).

As Yakov Mayakin, character of Russian author Gorky mentions, "We merchants, tradesmen, have for centuries carried Russia on our shoulders, and we are still carrying it", merchants constitute essential social class. As days pass, they got stronger and after year of 1861, they became the wealthiest layer of Russian society like nobels. They have typical form of life, adhere to traditions as seen in the examples of Russian painting art.

\section{A brief history of merchant class in Russia}

In Russia it is a fact that the first merchant was himself of the Tsar. The best goods were chosen by the workers of the Tsar and were brought into the palace. In addition to this, in the period of Aleksei Mihailovic Romonov the palace sold foreign merchants valuable goods like sepiolite, resin, Slavian food solo, fur and silk. In the beginning of 15th century Russia tried to contact with Europe. However in $16^{\text {th }}$ and $17^{\text {th }}$ centuries effect of West-Europe had scarcely started to be seen (2007).

The reforms of Peter the Great, who struggled to westernize Russia, did not bring significant favour for Russian merchant class. According to Tsar, trade had to become explicit and ordinate. However, domestic merchants, who got accustomed to the past, deep-rooted traditions, old-fashioned methods of the organization of trade, were not fully prepared for changes. In the year of 1721, "regular citizens", merchants and artisans, divided into first and second grade (Lizagub, 2013). In pursuit of this; according to regulations of Catherine the Great in 1775, merchants was composed of three different grades. Third grade merchants, which was the lowest, had to own 500-1.000 ruble, second grade merchants had to own 1.00010.000 ruble and first grade merchants had to own 10.000 or more of it. In 1863, the third grade was infirmable, only first and second grade existed (Fedosyuk,2016).

In the first half of the $19^{\text {th }}$ century, there was a slow progress in finance, trade and industrialization. The cities of Russia was not completely an industrial district; on the contrary administrative zone covered by church. Trade was not fully organized and required credit. Only in 1817 in Petersburg, the state trade bank and its branch offices in six different cities opened in order to provide credit and bill of exchang (Pushkarev,2001). The capital owners, the majority of which was the merchant class, were not entitled to a number of noble titles and privileges, but compensated for some honorary titles: 
"counselor-manufacturer", "commerce advisor"; finally personal and hereditary honourable citizens introduced in 1832. Accordingly, merchants, who have more than 100.000 ruble, were privileged citizen according to the law (Jukova, 2014). Honourable citizens acquired a number of benefits and privileges similar to those of noble (Fedosyuk,2016).

In the period of Alexander II, the emancipation reform of 1861 effectively abolished Russian serfdom. This reform caused important alternations in different areas. The abolition of serfdom and therewithal the revival of economic life, which began in 1860s, required critical city reform. The city reform, which published in 16 July 1870, was about urban management and agriculture; external landscaping of the city; providing food supply for population, arrangement of markets and bazaars; measures against fires; care for the development of trade and industry, arrangement of exchanges and credit institutions, arrangement of charitable institutions and hospitals, participation in the interest of education of society, arrangement of theatres, museums, libraries; submission to the Government on local use and needs (Pushkarev, 2001). After emancipation reform of the Russian serfs in 1861, population of merchant class in big cities increased. In the end of 19th century and in the beginning of 20th century, economic growth proceeded and merchant class got richer and stronger in comparison with the other layers of the society.

\section{Identification of merchants with the negative character trait}

Beginning from Ancient Greek, unfavourable meanings had been attributed to merchants. As historian Philip Curtin mentioned, "The earliest Hermes was god of the boundary stones, but he gradually became the god of the merchants, the professional boundary crossers. At the same time, he was not quite as respectable as the other gods - a messenger, but also a trickster and a thief, a marginal god for people who were marginal to Greek society. Plato himself disliked trade, which, like other professionals based on a search for profit, was hardly compatible with a life of virtue, as he understood it." (Curtin, 2002).

In Russia beginning from $19^{\text {th }}$ century, merchants were considered as despotism. This accusation showed up on the observations of painters, authors and critics whose aim was to disclose the reality and reflect it to the art. The pioneer of the tradition, which created merchant characters, is dramaturgist A.N. Ostrovsky. The playwriter critically observed merchant class and henceforward, merchant characters got on the stage. Merchants in early works of Ostrovsky differ from merchants after 1860s. Merchants became richer and intellectual however, they remained a tyrant. In 1859, Russian critic Dobrolyubov published an article entitled "the dark kingdom" (temnoe tsarstvo) about characters of A.N. Ostrovsky's plays and criticised the world of domestic tyranny.

Representatives of this tradition in Russian painting art followed the principle of reality in direction of the era. As seen in N.G. Perov's (1834-1882) painting named "The arrival of a governess in a merchant's house" (Priezd guvernantki v kupecheski dom, 1866), Nevrev's (1830-1904) painting named "Protodeacon proclaiming longevity at the merchant birthday party" (protodiakon, provozglashayushii na kupecheskih imeniyah mnogoletiye, 1866) and Firs Juravlev's (1836-1901) painting named "Merchant funeral dinner" (Kupecheskiye pominki, 1876), behaviours of merchants are rude, unrespectful and wilful. Each merchant in different paintings are an example of "the dark kingdom".

In the painting of Perov, the innocence and defendless of the young governess conflicts the aggressive looks of merchant. The repellent look of merchant to the naive governess is obviously seen in the painting of Juravlev, too. Except the looks, gestures are the other factor, which discloses the personality of merchants. In the painting of Nevrev, the merchant is observed that he clenchs and he is in a attack of nerves. In the painting of Perov, he puts his hand on his waist and in the painting of Juravlev, he puts one of his hand on table, other on the head of chair. These gestures are symbol of dominance.

Another painting that shows the rudeness and disdain of merchants is "Jokers, Merchant court in Moscow" (Shutniki, gostinıy dvor v moskve1865) painted by Pryanishnikov. This painting has a theatric composition. In the Moscow merchant court, a sivil servant is dancing in front of the merchants and salesmen. Three men stand back of dancing sivil servant; one of them meaningless looks at him, other one mercifully looks, the third one cruelly makes fun of him (1965). Mockery and malice against the poor civil servant reveal the pride and egoism.

\section{Merchant marriages as an agreement}

Marriage is very significant for merchant families. However, the issue is not only to settle down, but also to gain a profit or a tittle. In other words, marriage is an agreement between two families for merchants. When the family became poor day- 
by-day, marriage of the young daughter is a solution to improve financial situation and earn reputation. Therefore, most of the merchant married with nobles. Nevertheless, the best option was that most young merchant married their relatives, and by the end of the 19th century the majority of merchant generation was closely connected with family ties through sonin-laws and daughters-in-laws (Jukova, 2014).

This bitter reality is also one of themes in $19^{\text {th }}$ century Russian painting art. Fedetov and Juravlev dramatically describe forced marriage. In the both painting, the composition is disheartening: the head of the family decides that his daughter marry with a man chosen by himself. It is the tragedy of the daughter in a wedding dress.

The essense of Fedetov's approach to art was to reconstruct the ugly behind the beautiful and to expose the true nature of the society based on deception and hypocrisy. Fedetov pursued the aim through the combining of the poetical and critical aspects of art (Saravyanov, 1990). In the painting named "major's wedding proposal" (svatovstvo mayora), the created composition is harmoniously dynamic: the gesture of the bride who does not want to marry, proudly waiting of the major at the door, tugging of the mother at her daughter's wedding dress, standing of long-bearded merchant in traditional costume, champagne and wine glasses on the table waiting for celebration, even the cat's licking its hair off are inseparable parts of the painting. Fedetov uses power of light and colour contrast. The bride in pink and white conflicts the dark figure of the major and merchant-father in black.

In the painting named "before the wedding" (pered ventsom, 1874) Juravlev uses the same technique of colour contrast like Fedetov: a merchant father in black holding an icon on his hand and a daughter in white wedding dress crying on the floor. The hands of merchant and her daughter reveal the tension. Stamping with rage, he is grasping the handkerchief on his hand; on the other hand feeling deep sadness, she closes her face with both of her hands. Merchant's wife looks very sad. The reflection of her sad face to the mirror enhances the tragedy of the composition. Through traditions, it is possible that mother had lived the same tragedy.

\section{Daily life and ethnographic details of mercants in $19^{\text {th }}$ century}

Before $19^{\text {th }}$ century painting art, characters of merchant class is rarely described. Therefore the painting named "Merchant family in $17^{\text {th }}$ century" (Sem'ya kuptsa v XVII veke) completed by A.P.Ryabushkin (1861-1904) in 1897, is a significant guide that points out the ethnographic details of merchant family and the flow of time. In this painting typical traditional merchant family in $17^{\text {th }}$ century and the Russian daily life before rulership and progressive reforms of Peter the Great are remarkable. Although Ryabushkin lived in the end of 19th century, he was interested in exploring the history and he successfully reflected historical knowledge to his paintings. The artist reveals clues of merchants daily life; wealth and welfare of merchant family are displayed. In the centre of the painting sits the merchant, head of the family. He selfassuredly looks; as a merchant, he symbolises dominance, power and success. Every member of the family pose in front of painter except the little boy sitting down on his mother's lap. The dynamic position of the boy creates a feeling of aliveness. Artist focused on qualified materials and patterns of the costumes, jewellery, make-up, the doll of little girl in order to reveal wealth. The painting leaves an impression of parsuna under favour of Ryabushkin (1960).

As seen in the paintings, the apparence of merchant between $17^{\text {th }}$ and the first half of $20^{\text {th }}$ century did not change so much. One of the reason of that, merchants was keen on traditions and close to new ideas. The most important detail about appearance of merchant is beard. In Russia typical merchant has a long beard which symbolises traditions, manhood and wisdom. In addition to this, there was a belief that long bearded merchants were good at trades (Vistengof, 2004). After year of 1861, education level got higher and appearance of merchants started to change. Upper class merchants shaved and smooth-faced merchants symbolized westernise. Here it should be emphasized that Peter the Great, who attempted to westernize Russia, laid a tax on beard. Beard tax was not for merchants, yet it discloses the conflict of westernising and a beard. However, in spite of the attempts of change, old-fashioned merchants saved their traditional appearance like the merchant described by Kustrodiev (1878-1927) in 1918.

One of the first merchant character in genre art painting was descriped by Fedetov in the painting named "major's wedding proposal" (svatovstvo mayora). Life standards of the merchant described by Fedetov is not as good as the life of merchant described by Perov. Merchant described by Fetedov belongs to the period before 1861 and view of life totally changed. Merchant wife in the first half of $19^{\text {th }}$ century is also different from merchant wife drinking tea described by Kustodiev in 1918. Only irreplaceable tea ceremony remains over in daily life of merchant class. 
As mentioned before, merchant class after 1861 started to gain more capital and became richer and this is the biggest reason of the change. The alternation is about not only their financial situation, but also the level of education and culture. Before 1860s merchants who never went to theatre, became a regular audience member of theatre plays and operas. Life of rich intelligent merchants was almost the same as life of nobles: the same balls, dinners, guests, tutors and governesses for the children, European dresses, same atmosphere in the rooms, collections of curiosities, paintings, gravures and creation of extensive and valuable library (Belovinskiy, 2014).

\section{Conclusion}

Observing sociocultural structure of merchant class, the connection of $19^{\text {th }}$ Russian painting art with reality ensures that genre painting is a guide for daily life details in history. In the early $20^{\text {th }}$ century painting art, research about history of merchants and merchant portrait series provide ethnographic information.

As a result, through the history merchant class struggle to gain power and successfully made it real. However, this power brings them bad reputation. Writers, painters, critics objectively observed and disclosed it. Regardless, it is an important fact that power of merchant class means power of the country.

\section{References}

[1] (1960) İstoriya russkogo iskusstva. Tom II, red V.A.Prıtkov moskva, İskusstvo.

[2] (1965) istoriya russkogo iskusstva IX. Moskva, Akademia nauk.

[3] (2007). Moskva kupechestvo torgovlya XV- nachalo VV veka. red. A.R. Andreev, Moskva, Kraft.

[4] Belovinskiy L.V.(2014) Jizn russkogo obıvatelya ot dvortsa do ostrogo. Moskva, Kuchkovo pole, 2014.

[5] Curtin Philip D. (2002). Cross Cultural trade in world history. Cambridge, Cambridge University.

[6] Fedoysuk Yu.A (2016). Chto neponyatno u klassikov ili entsiklopediya russkogo bıyta 19 veka. Moskva, Flinta.

[7] Jukova, (2014). Russkoe kunechestvo. Moskva, Veche.

[8] Lizagub, V.A., Lahno V.I. (2013). Status kupechestvo v epohu Petra I, problemıy zakonnosti. no:123, http://cyberleninka.ru/article/n/pravovoy-status-kupechestva-v-epohu-petra-i-1, 1.09.2016.

[9] Pushkarev, S.G., (2001.) Rossiya 1801-1917: Vlast i obshestvo. Moskva, Posev.

[10] Saravyanov D.V. (1990). Pavel Andreyevich Fedetov. Leningrad, Hudojnik RSFSR.

[11] Vistengof, P. Kokorev I.T. (2004), Moskva v ocherkah 40h godov 19 veka. Moskva, Kraft.

\section{Tables}

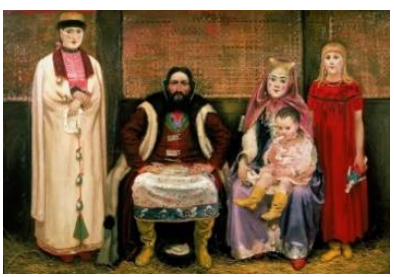

Ryabushkin, Merchant family in 17th century (Sem'ya kuptsa v XVII veke), Oil on canvas, $143 \times 213 \mathrm{~cm}, 1896$, Russkiy Museum, Saint Petersburg, Russia

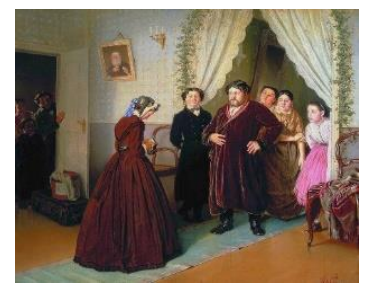

V.G.Perov, The arrival of a governess in a merchant's house birthday party, Oil in Canvas, $44 \times 53.5 \mathrm{~cm} ., 1866$, Russian Museum, Saint Peterburg, Russia

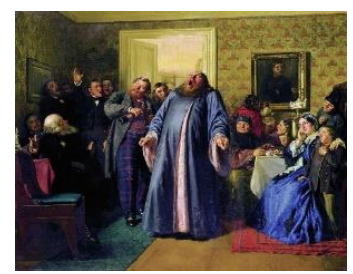

Nevrev, Protodeacon proclaiming longevity at the merchant, Oil in Canvas, 60,4 X $73 \mathrm{~cm}, 1866$, Tretyakov Gallery, Moscow, Russia 

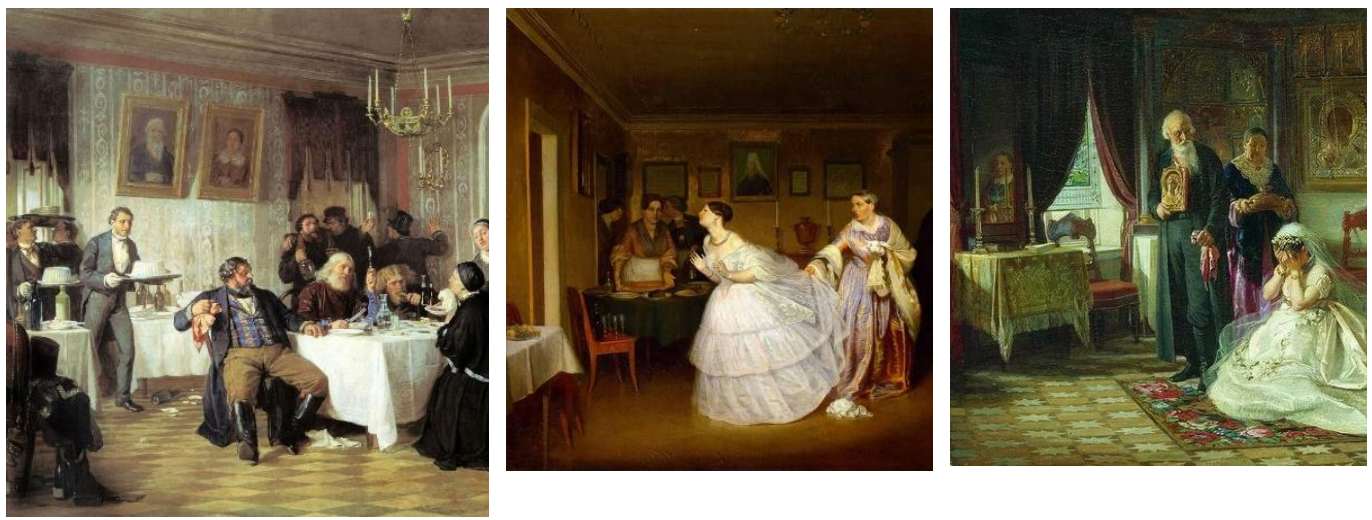

Juravlev, Merchant funeral dinner, Oil in canvas, 98X $142 \mathrm{~cm}, 1876$, Tretyakov Gallery, Moscow, Russia
Fedetov, Major's wedding proposal, Juravlev, Before the wedding, Oil in Oil in canvas, 58,3X75,4,1848, canvas, $105 \times 143 \mathrm{~cm}, 1874$, Tretyakov Gallery, Moscow, Russia Tretyakov Gallery, Moscow, Russia

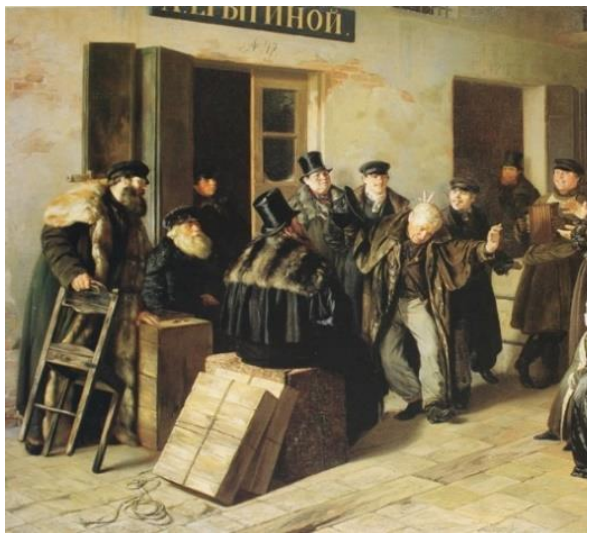

Pryanishnikov "Jokers. Merchant court in Moscow", Oil in Canvas, 63,4 X 87,5, 1865 . Tretyakov Gallery, Moscow, Russia

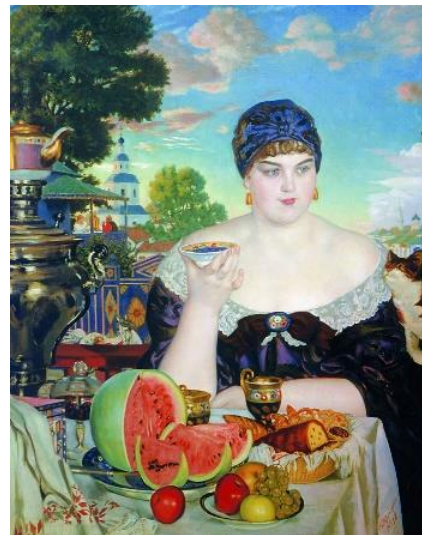

Kustodiev, Merchant's wife, Oil in canvas, 120,5x121,2, 1918, Russian Museum, Saint Peterburg, Russia

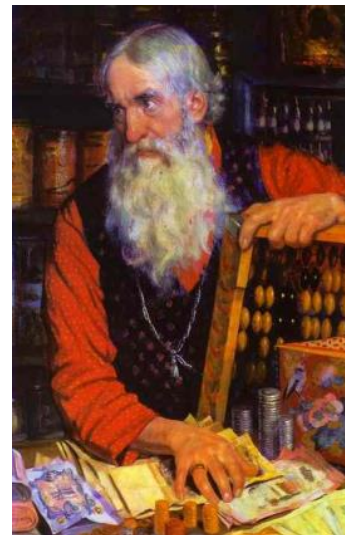

Kustodiev, Merchant, Oil in canvas, 88.5 x $70 \mathrm{~cm}, 1918$, Brodski museum, Saint Peterburg, Russia 